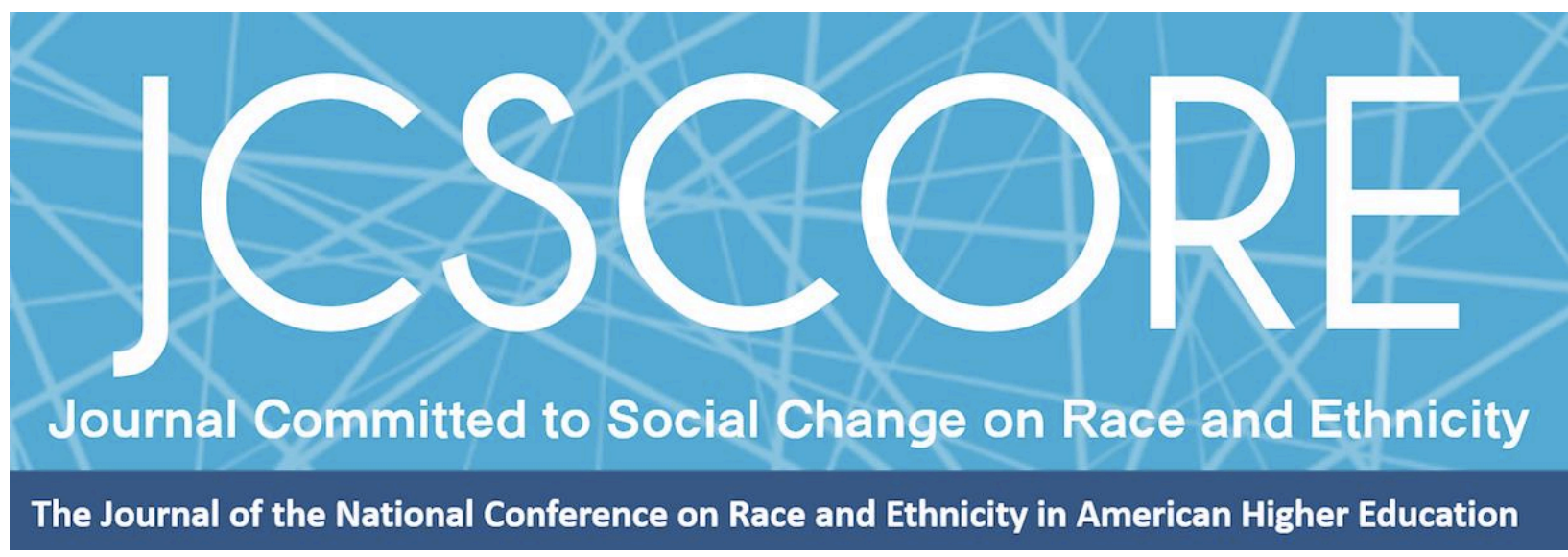

\title{
YOUR TRUE COLORS
}

\author{
Ana Guerin \\ Florida Atlantic University
}

Journal Committed to Social Change on Race and Ethnicity

Volume 7, Issue 2 | 2021

\section{Copyright and Open Access}

(C) 2021 Ana Guerin

\section{cc) (1) (2)}

This work is licensed under a Creative Commons Attribution-NonCommercial-ShareAlike 4.0 International License. Permission of the authors is required for distribution and for all derivative works, including compilations and translations. Quoting small sections of text is allowed as long as there is appropriate attribution and the article is used for non-commercial purposes.

The Journal Committed to Social Change on Race and Ethnicity (ISSN 2642-2387) is published by the National Conference on Race and Ethnicity (NCORE), a production of the University of Oklahoma, in partnership with the University of Oklahoma Libraries. 


\title{
Your True Colors
}

Ana Guerin

Florida Atlantic University

\begin{abstract}
This poem reflects the author's heartbreak, disappointment, and the realization that people may not show who they truly are to one. The author describes feeling disappointment and a sense of guilt from a previous relationship. The person she thought she knew turned out to be someone who did not align with her values. The author is a Mexican American woman who immigrated to the United States as a teenager from Mexico. She found within herself to educate herself through her adult life seeking to erase internalized patriarchy and oppression. Living through such divisive political environment between 2017 and 2020, she began to realize people around her, in specific the relationship illustrated in the poem, were not who she thought they were. The author describes the end of the relationship with a play on words declaring that she does not want to see this person's dull colors again.
\end{abstract}

You were not lying to me,

You were lying to yourself, You showed me this person, When I thought your core values resembled mine, It was all a lie.

Were you only protecting your privilege?

Were you afraid to show me who you truly are?

Were you afraid I was going to turn around?

At the time we were both crumbling,

Your true colors made the decision to choose our battles,

An easier one to accept and move on.

You said kneeling for the national anthem

Had no place in sports,

You said scholarships for marginalized groups

Were special handouts,

You laughed and mocked a female body

And questioned why I had no expression on my face,

You said the word gay was funny,

You said oppressive leaders deserved their monuments,

And changing would erase history,

You defined social warriors

As complainers and whiners,

Could not even acknowledge your able body privilege.

As I sit here and reflect, 
On everything you said, I wonder where you hid behind all this time.

I cried to you not knowing,

Why you were not able to grow with me.

Now I wonder, if other people around me,

Are also hiding their true colors.

Do I plant the seed to intimidate bigotry?

Though you walked on eggshells around me,

I hope you know there are groups

Walking on eggshells around you.

I hope one day they will be brave enough

To show their true colors to you,

I hope you learn from them,

Since you did not learn from me,

I was unable to fight this battle.

After so many years of knowing you,

How dare you mansplain to me,

That I do not look like my nationality,

My heart had already been broken from previous statements,

But this last one...

I knew I had forever lost you.

And even after I took you under my wing

To experience other colors,

You decided to put blinders,

So, then I knew I had lost this battle to you

Your privilege, your bigotry, your medieval ways,

Your dull colors,

I never want to see again. 